Article

\title{
Coupling Riverbank Filtration with Reverse Osmosis May Favor Short Distances between Wells and Riverbanks at RBF Sites on the River Danube in Hungary
}

\author{
Endre Salamon $(\mathbb{1}$ and Zoltán Goda * $[\mathbb{C}$ \\ Faculty of Water Sciences, National University of Public Service, 6500 Baja, Hungary; salamon.endre@uni-nke.hu \\ * Correspondence: goda.zoltan@uni-nke.hu; Tel.: +36-70-374-2674
}

Received: 28 November 2018; Accepted: 4 January 2019; Published: 10 January 2019

check for updates

\begin{abstract}
Bank filtration and other managed aquifer recharge techniques have extensive application in drinking water production throughout the world. Although the quality of surface water improves during these natural processes, residence time in the aquifer and length of the flow paths are critical factors. A wide range of data is available on the physical-chemical processes and hydraulic conditions, but there is limited knowledge about the top layer of the porous media. An investigation was conducted on the hydraulic behavior and on the change of microbiological indicator parameters in the filter cake. The purpose of the experiment was to: (1) investigate if the reverse osmosis is sustainable when fed with only slow filtered water, and (2) show that a short travel distance can provide extensive pathogen removal and beneficial conditions for the reverse osmosis. A slow sand filter was operated over a one-year long period while changes in head loss and microbiological parameters were being monitored. Head loss and membrane permeability were monitored between 3 November 2016 and 24 October 2018 and microbiological sampling was performed from 19 July 2017 to 6 November 2018. The filtered water was fed to a reverse osmosis (RO) filter as the water above the sand filter had been spiked with dissolved iron. Results show that even a thin biofilm cake of 1-3 mm thickness can result in a significant (10-100\%) reduction in microbiological activity in the infiltrate, while favorable short retention times and oxic conditions are maintained. Avoiding anoxic conditions, subsequent iron and manganese dissolution and precipitation is beneficial for membrane processes. Building on these results, it can be stated that when reverse osmosis is directly fed with slow filtered or bank filtered water, (1) a short distance from the surface water body is required to avoid dissolved iron and manganese from entering the groundwater and (2) proper pathogen rejection can be achieved even over short distances.
\end{abstract}

Keywords: bank filtration; biofilm; clogging; filter cake; pathogen barrier; pressure loss; slow sand filtration

\section{Introduction}

Due to the increasing strain on drinking water supplies and the energy demand for drinking water treatment, the combination of natural and engineered systems (CNES) gains more and more attention. While the currently reported annual volume of managed aquifer recharge (MAR) is only $1 \%$ of global groundwater use, in some countries it is considerably higher, especially where river bank filtration (RBF) is practiced, e.g., in Hungary, the Slovak Republic and Germany [1]. Although the benefits of these processes are well-known and they have been studied extensively over the last century, some unresolved site-specific issues and ambiguous scientific terminology remain. In Hungary, with the exception of the RBF sites on islands in Budapest, it is typical for smaller rivers that had elevated 
concentrations of dissolved iron and manganese in the portion of pumped land-side groundwater to require further water treatment [2].

The Fe and $\mathrm{Mn}$ issue is hydrogeology related, and it involves the distance between the surface water body (rivers in the case of RBF, infiltration trenches and basins in the case of MAR) and the abstraction point. If the abstraction point is far away (horizontally or vertically) from the surface water body, undesired flow from the background/land-side commonly increases, causing higher dissolved iron and manganese concentrations in the pumped water. On the other hand, if the flow path length is short, the withdrawal of surface water increases, but the short retention time reduces the efficiency of the porous media as a barrier and bioreactor.

A large number of publications are dealing with the question of how distance and travel time affect the removal capacity of MAR schemes [1]. Hydraulic conditions and physical and chemical changes have been extensively studied. Due to limitations concerning the calibration of geohydrochemical models, there is a lack of data on the exact spatial extent of water quality changes on the subsurface. It is understood from the slow sand filtration process that the highest (micro)biological activity is found at the topmost few centimeters of the filter. The flow velocity in slow sand filters $(1-50 \mathrm{~cm} / \mathrm{h})[3,4]$ are comparable with those documented for BF sites $(0.1-50 \mathrm{~cm} / \mathrm{h})[5,6]$.

Both sand filtration and bank filtration were studied extensively in the past regarding the rejection of potential microbiological hazards. In slow sand filters, 1-3 log removal (90-99.9\%) was observed by different authors, both by colony counting and other methods $[7,8]$. RBF was reported to be capable of 2-5 log reduction for pathogen indicator parameters, such as E. coli and coliforms [9,10].

Consequently, with respect to the importance of the first few centimeters of the top layer, both RBF and MAR in general have some analogy with slow sand filtration and cake filtration. Since long residence times and flow path lengths can have an adverse effect on water quality, it raises the question about the extent that this thin boundary layer (or zone) can be utilized in order to avoid discharge from land-side or deeper groundwater.

Concerning RBF, a large number of scientific studies dealt with clogging and flow conditions in the riverbed, and various methods were applied and further developed to assess the permeability of the riverbed, i.e. the fragment approach and complex numerical flow simulation models [11,12]. The main difference between a pure slow sand filtration setup and RBF is the presence of the shear stress and sediment transport at the boundary coupled with an abstracted portion of land-side groundwater. With respect to MAR, the shear force at the boundary is usually negligible, depending on the specific layout and hydraulic conditions of the infiltration structures. Because of this, MAR is more closely related to slow sand filtration.

As part of the AquaNES "Demonstrating Synergies in Combined Natural and Engineered Processes for Water Treatment Systems" project, a slow sand filter was operated at the pilot water treatment plant (PWTP) of the National University of Public Service's Faculty of Water Science in Baja, Hungary. The aim of the study described here was to assess the efficiency of slow sand filtration when a thin, clogged, biologically active top layer is present. This way an assessment can be made about the removal of pollutants and pathogen retention at the porous media-water body boundary. Results are compared with the efficiency of long retention time systems. The investigation is focused on determining the extent of reduction in microbiological indicator parameters.

The main application of reverse osmosis is seawater and brackish water desalination in the present day. Even though there is considerable drinking water production by reverse osmosis worldwide, most scientific research focuses on the process itself and extensive case studies do not exist for bank filtration coupled with reverse osmosis. The main area of the present research is the rejection of pollutants, which are known to be unaffected by bank filtration [13]. Other research focuses on the energy efficiency [14] as reverse osmosis (RO) equipment used for freshwater desalination operates on a considerably lower pressure and energy demand than those for seawater desalination. A similar pilot scale investigation with single element $\mathrm{RO}$ was carried out at three different sites in the United States [15]. In developed countries, reverse osmosis of freshwater is typically used for wastewater 
reclamation and is usually located at the end of the process train either in wastewater treatment or drinking water treatment, for example in Orange County, California [16].

Although large water companies and some authorities possess reverse osmosis equipment for emergency water treatment, the long-term treatment of bank filtered water on reverse osmosis has never been studied in Hungary. Bank filtration supplies almost $50 \%$ of the country's drinking water demand and bank filtration sites are vulnerable to not just emerging micropollutants, but industrial and municipal wastewater discharge as well. Therefore, it is imperative to start investigations on the long-term sustainability of advanced treatment processes.

In order to investigate the impact of the bank filtration process on membrane filtration, a reverse osmosis (RO) filter was installed on the filtrate stream. This unique setup (despite RO never having been the first choice for treating fresh water in the past) was chosen because among all membranes, $\mathrm{RO}$ is the most sensitive to fouling. Because $\mathrm{RO}$ operating parameters respond very rapidly to fouling effects, it could be a good choice to investigate the impact of naturally treated water quality on engineered processes. If it can be proven that a thin boundary layer is adequate during MAR or even RBF to properly improve the water quality for membrane filtration, then more CNES systems with short retention times may be developed in the future.

\section{Materials and Methods}

\subsection{Slow Sand Filter Setup}

The experiment was carried out in a fully saturated open rapid sand filter structure (Figure 1). The grain size distribution of the $1 \mathrm{~m}$ thick sand layer shows mainly grains between $0.5-0.8 \mathrm{~mm}$ (11\%) and $0.8-1.5 \mathrm{~mm}(87 \%)$ and larger than $2 \mathrm{~mm}(1.4 \%)$, with $0.6 \%$ of grains smaller than $0.5 \mathrm{~mm}$. The supporting gravel layer consists of $2-5 \mathrm{~mm}$ pebbles (100\%). A constant filtration rate of $50 \mathrm{~mm} / \mathrm{h}$ was maintained by constant withdrawal of the filtrate with the help of a centrifugal pump $(\mathrm{Q}=260 \mathrm{~L} / \mathrm{h}$, type FC 25-2C, SAER, Guastalla, Italy) with throttle control. Raw water was extracted directly from Sugovica, a branch of the Danube river on a daily basis. Daily change of the water depth above the sand layer was 1.0-1.5 $\mathrm{m}$ and a minimum coverage depth of $0.8 \mathrm{~m}$ was maintained at all times.

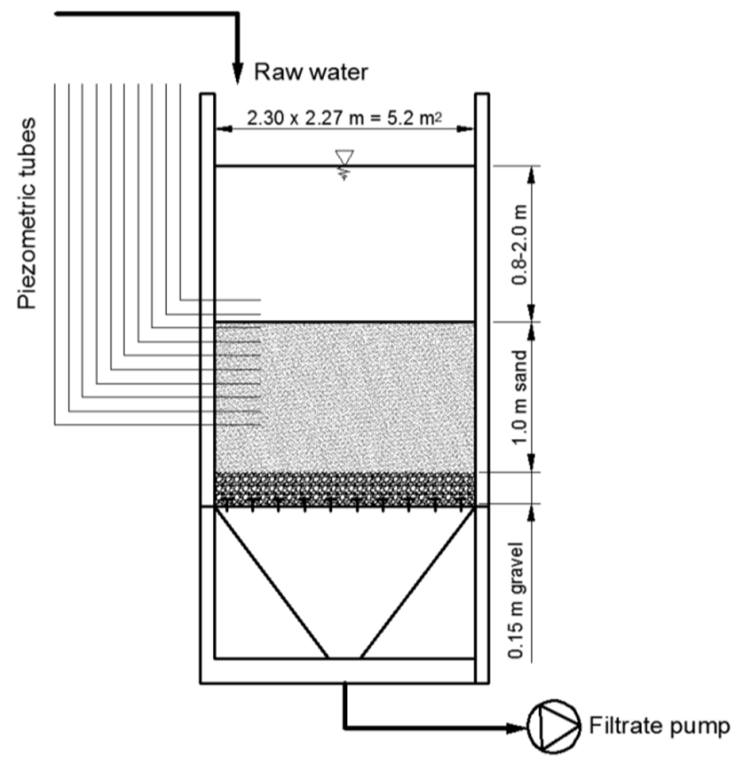

Figure 1. Slow sand filter layout.

Piezometric tubes (silicone rubber, nominal diameter $=8 \mathrm{~mm}$ ) were installed at different depths in the sand layer. The distribution of the piezometers along the sand layer is detailed in Table 1. The inlets of the tubes were covered with geotextile in order to prevent the sand grains from entering 
and clogging the tubes. A vacuum pump was installed on a joint collector headspace of the piezometer tubes. Since this system has a closed headspace, once the vacuum pump is turned off, the differences between water levels in the piezometric tubes reflect the pressure differences between the tube inlets. These differences were subtracted from the calculated hydrostatic pressure in order to obtain the pressure distribution. The purpose of the two inlets above the sand layer is to signal if any obstruction, clogging or biofilm growth takes place on the protective cover at the inlet.

Table 1. Piezometer distribution.

\begin{tabular}{cc}
\hline Piezometer No. & Inlet Depth from Sand Layer Top $(\mathbf{c m})$ \\
\hline 1 & 105 \\
2 & 82 \\
3 & 62 \\
4 & 43 \\
5 & 21.5 \\
6 & 5.5 \\
7 & $8 \mathrm{~cm}$ above sand layer \\
8 & $37.5 \mathrm{~cm}$ above sand layer \\
\hline
\end{tabular}

Differences in piezometric levels were registered daily in order to monitor the clogging of the top layer. In order to read the level differences between the piezometers, manual reading was applied. Before reading the piezometers, the water raised to eye-level with the vacuum pump and all air bubbles were removed from the tubing. After the levels stabilized (5-15 min), the differences between each piezometer were registered.

\subsection{Reverse Osmosis Unit}

Filtrate from the slow sand filter was fed to small RO filter, which had a pressure booster and a $5 \mu \mathrm{m}$ cartridge filter of its own. The RO unit contained cross-flow, spiral wound composite (thin film) membranes (manufacturer: General Electric, catalog number: AK2540TM, Boston, MA, USA) in two vessels (Figure 2).
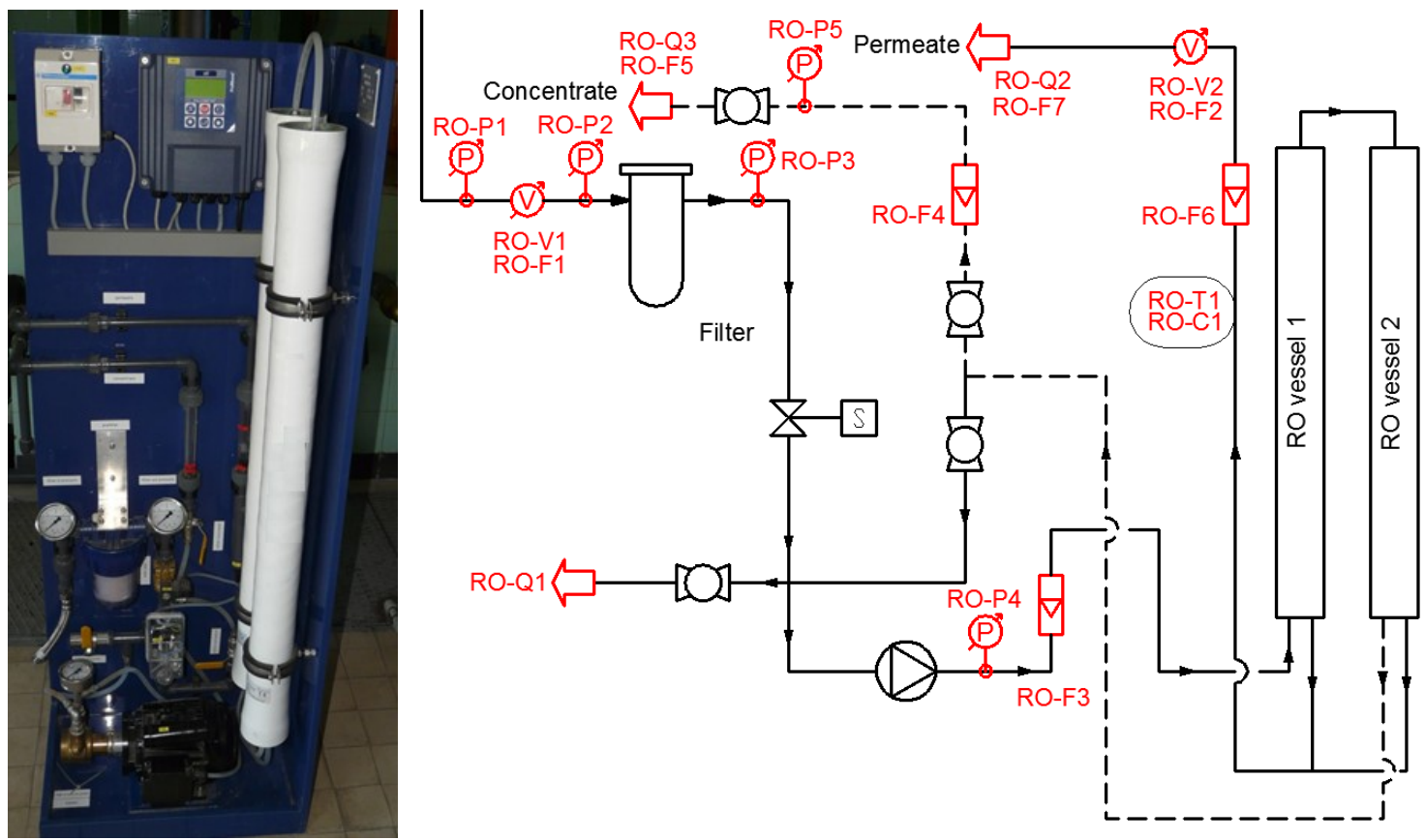

Figure 2. Small scale reverse osmosis $(\mathrm{RO})$ unit (measurement points: $\mathrm{F}=$ flowrate; $\mathrm{C}=$ conductivity; $\mathrm{P}=$ pressure; $\mathrm{Q}=$ sampling; $\mathrm{T}=$ temperature; $\mathrm{V}=$ volume). 
At the beginning of each filtration cycle, the recovery ratio was set to $50-60 \%$ and the initial throttle on the concentrate outlet and on the concentrate recycle was left undisturbed. This way, as the filtration went on, the permeability slowly declined due to membrane fouling. Daily average feed, concentrate and permeate quantities were determined based on installed water meters. Transmembrane pressure was calculated based on the average of feed and concentrate pressure.

\subsection{Sampling and Analysis}

Weekly and bi-weekly sampling for microbiological parameters was conducted according to the Hungarian MSZ EN ISO 19458:2007, sampling for microbiological testing standard [17] between November 2016 and October 2018. The samples were sent to the laboratory of Budapest Waterworks (BUWW) for analysis (Table 2). Parallel samples were taken on the same day and the colony count was determined on site in the PWTP laboratory as well.

Table 2. Measured microbiological parameters and applied standard methods.

\begin{tabular}{cc}
\hline Parameter & Standard Method of Analysis \\
\hline Colony count, $22^{\circ} \mathrm{C}$ & MSZ EN ISO 6222:2000 \\
Colony count, $37^{\circ} \mathrm{C}$ & MSZ EN ISO 6222:2000 \\
Coliforms & MSZ EN ISO 9308-1:2015 \\
E. coli & MSZ EN ISO 9308-1:2015 \\
Enterococcus & MSZ EN ISO 7899-2:2000 \\
Clostridium (anaerobic sulfate reducers) & MSZ EN 26461-2:1994 \\
Pseudomonas aeruginosa & MSZ EN ISO 16266:2008 \\
\hline
\end{tabular}

Two samples were taken at each sampling, one from the raw water above the sand filter and one from the filtered water. The sample from the raw water was taken by a thoroughly rinsed metal bowl dipped in the open water above the filter. Samples from the filtrate were taken from a sampling tap installed on the filtrate pipe. The tap and the pipeline were rinsed with $1 \%$ hypochlorite solution before and after every sampling.

\section{Results}

\subsection{Clogging and Pressure Loss Development}

Based on the measured piezometric level differences at different depths in the sand layer of the filter, the pressure distribution (or hydraulic gradient) was calculated along the filter in the form of a Michau (or Lindquist) diagram (Figure 3). The difference shown at a depth of $150 \mathrm{~cm}$ above the bottom of the filter indicates different water levels above the surface of the filter (water column of 1.0-1.5 m).

As expected, the pressure distribution shows the characteristics of a slow sand filter, with the steepest gradient present in the top $5 \mathrm{~cm}$ of the sand layer and no observable deviation from the linear gradient below. A deviance from the linear hydrostatic pressure can be attributed to the biofilm development on the geotextile covering the outlets of the piezometer tubes. This affected only the tubes near the top of the sand. Because of this, the equalization of the pressure differences in the piezometers takes a longer time.

The gradient in the top layer plotted as a function of elapsed time shows an increasing linear tendency (Figure 4). The calculated $p$-value of the F-test performed to investigate the linear correlation is $1.6 \times 10^{-5}$. At a 0.05 confidence level, it can be rejected that there is no linear correlation. The error of the slope is $3.86 \pm 0.53 \mathrm{~cm} / \mathrm{d}$. In spite of the large number of influencing factors, the increase of the gradient indicates an effective rejection of suspended solids and microbial growth. 


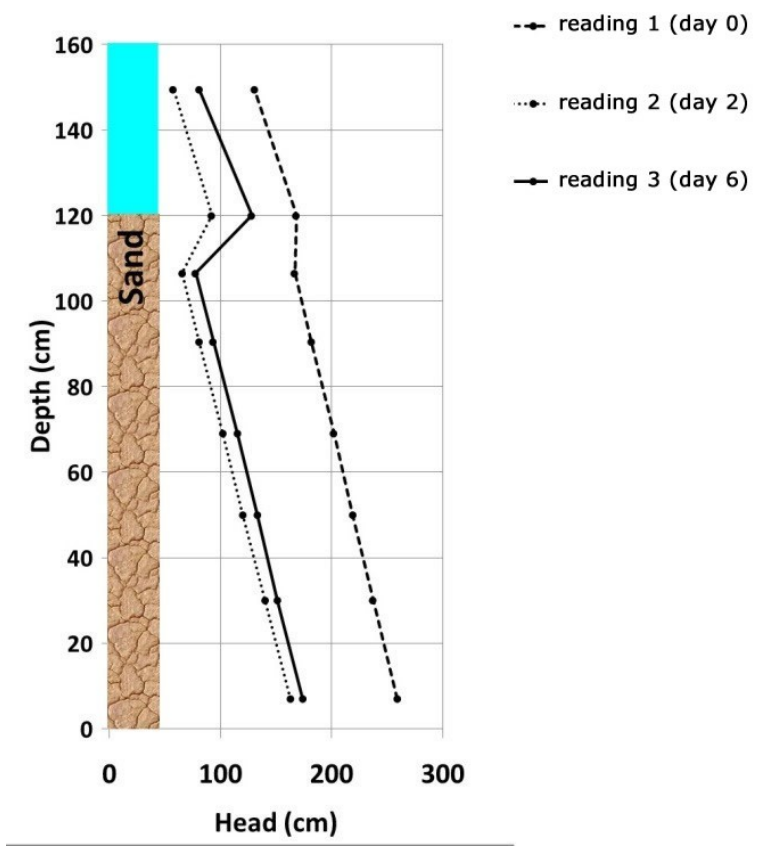

Figure 3. Measured pressure distribution in filter.

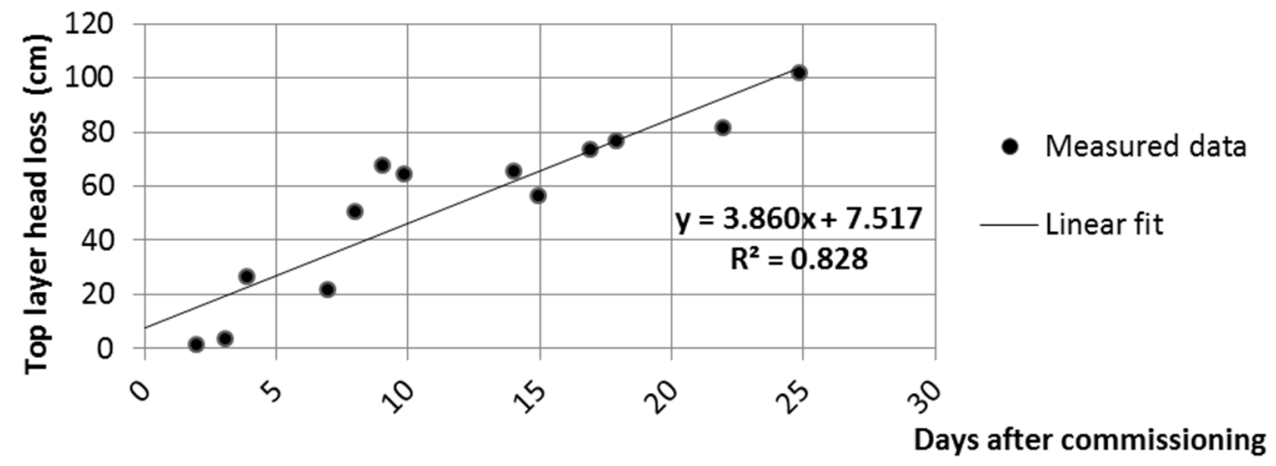

Figure 4. The relationship between the top layer and the days after commissioning.

The gradient and the resistance build-up are subject to many influencing factors apart from the microbiological growth and biofilm development. Combined, these factors can cause large random variations in the hydraulic gradient and the development of the resistance against filtration. Such factors include:

- sedimentation of small particles (e.g., in stagnant river areas),

- erosion of the top boundary layer (e.g., during floods or dredging),

- three-phase flow (e.g., gas bubbles from biological activity),

- non-zero order biomass growth (fluctuations in substrate concentration, temperature, $\mathrm{pH}$, etc.),

- changes in viscosity,

- precipitation and dissolution of carbonates, iron-hydroxides and other compounds at the boundary.

Under the conditions of the experiment, the rate of the resistance build-up was $4 \mathrm{~cm} / \mathrm{d}$ (cm stands for the measured difference in the piezometric levels). The developed biofilm and boundary layer could be observed with the naked eye after 1-2 weeks of operation (Figure $5 \mathrm{a}-\mathrm{c}$ ). Its thickness was 2-3 mm. 


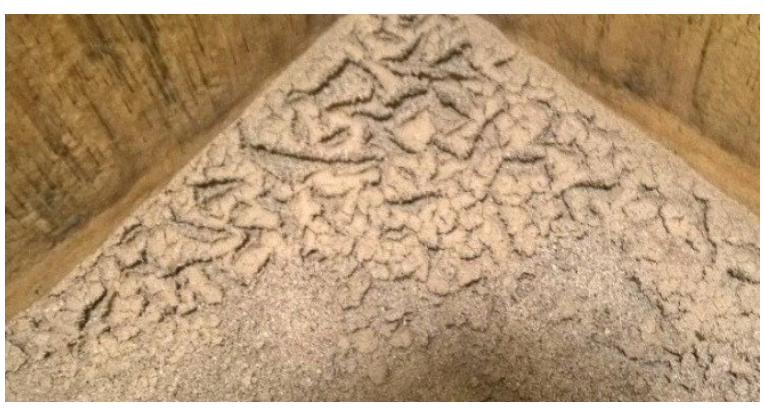

(a)

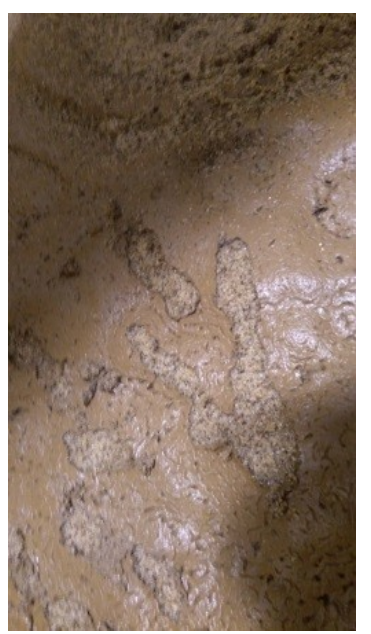

(b)

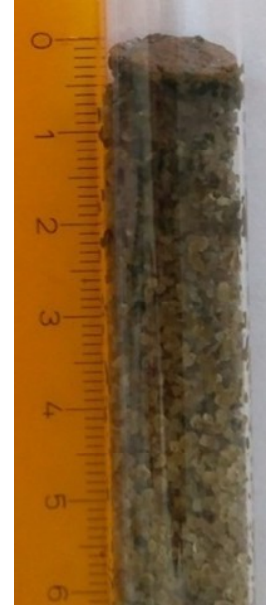

(c)

Figure 5. Clogged layer at the porous media-water boundary. (a) Dried state; (b) wet state; (c) approximate thickness of $2-3 \mathrm{~mm}$.

\subsection{Changes in Microbiological Indicator Parameters}

A box plot was created for the measured values of each parameter in the raw and in the filtered water (Figure $6 \mathrm{a}, \mathrm{b}$ ). Some results for coliforms and E. coli were omitted, because four samples could not be analyzed for $E$. coli by the BUWW laboratory due to the unexpectedly high interference from all other microbiological growth. In case of E. coli and Enterococcus, only 1-3 non-zero results were obtained and only the minimum (0), the maximum and the average are shown on the graph. The number of samples is also given after the name of the parameters.

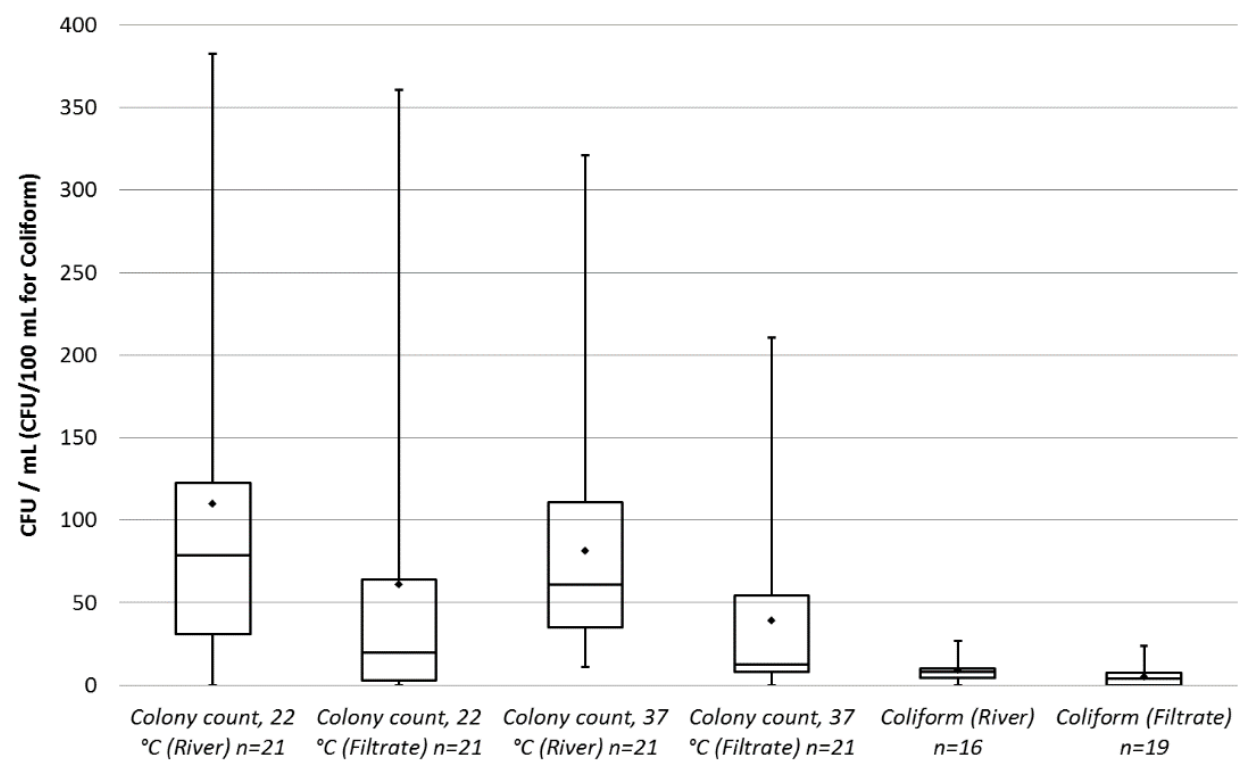

(a)

Figure 6. Cont. 


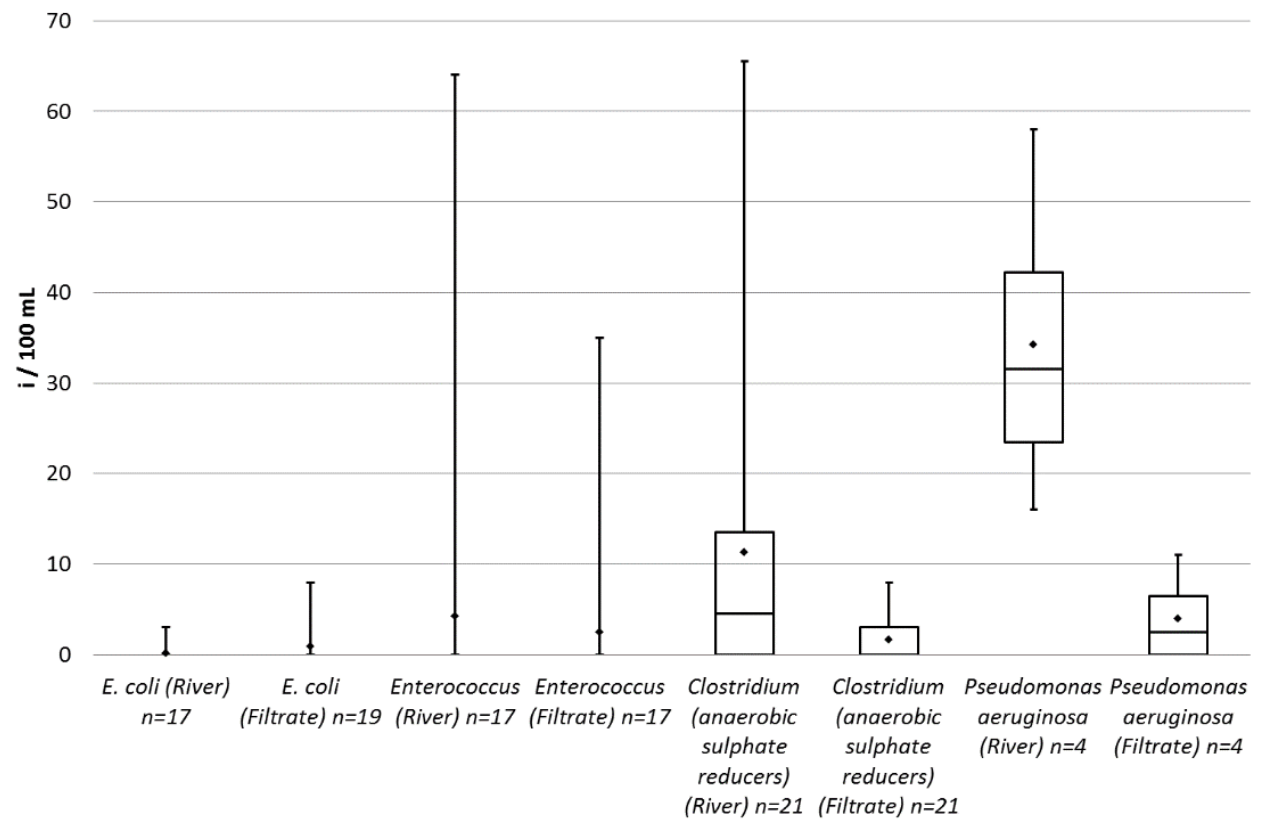

(b)

Figure 6. Values of microbiological indicator parameters. CFU = colony forming units, $\mathrm{i}=$ individuum.

(a) Parameters measured as CFU, (b) Parameters measured as individual entities.

All parameters, except $E$. coli, have a lower average and median in the filtrate compared to river water. E. coli was present in only one river and two filtrate samples: $3 \mathrm{i} / 100 \mathrm{~mL}$ (individuum/100 $\mathrm{mL}$ ), $6 \mathrm{i} / 100 \mathrm{~mL}$ and $3 \mathrm{i} / 100 \mathrm{~mL}$ respectively. Therefore, there is insufficient data to evaluate the change during the filtration for $E$. coli. The reduction in percentage was calculated for every parameter based on the raw water samples with non-zero values (Table 3).

Table 3. Reduction of microbiological indicator parameters.

\begin{tabular}{|c|c|c|c|c|c|}
\hline \multirow{2}{*}{ Parameter } & \multicolumn{3}{|c|}{ Reduction in \% } & \multirow{2}{*}{$\begin{array}{l}\text { Number of Non-Zero } \\
\text { River Water Samples }\end{array}$} & \multirow{2}{*}{$\begin{array}{l}\text { Number of Filtered Water Samples } \\
\text { with Zero Result ( } 100 \% \text { Reduction) }\end{array}$} \\
\hline & Minimum & Average & Maximum & & \\
\hline Colony count, $22^{\circ} \mathrm{C}$ & 15 & 43 & 100 & 16 & 2 \\
\hline Colony count, $37^{\circ} \mathrm{C}$ & 10 & 39 & 100 & 18 & 2 \\
\hline Coliforms & 20 & 41 & 100 & 10 & 3 \\
\hline Enterococcus & 45 & 68 & 100 & 3 & 1 \\
\hline Clostridium & 16 & 80 & 100 & 15 & 8 \\
\hline Pseudomonas aeruginosa & 57 & 81 & 100 & 4 & 2 \\
\hline
\end{tabular}

Twenty samples were analyzed for each parameter, except for Enterococcus (17 samples) and Pseudomonas aeruginosa (four samples). Both the raw water and the filtered water showed high variation in the measured concentrations. Based on the average reductions, the box diagrams and the non-zero samples from river, the most effective reduction is achieved regarding Pseudomonas, Clostridium and colony count. Coliform and E. coli numbers were close to zero at all times. This is due to the clean state of the source water and to the lack of any significant fecal contamination and wastewater discharge during the sampling period.

A paired $t$-test was carried out on all parameters except $E$. coli, which has too much zero measured data (Table 4). At a 0.05 significance level, it can be rejected that there is no difference between samples from the river and the filtered water for all parameters, except for coliforms and Enterococcus. 
Table 4. Paired $t$-test results.

\begin{tabular}{ccccccc}
\hline & $\begin{array}{c}\text { Colony Count, } \\
\mathbf{2 2}{ }^{\circ} \mathbf{C}\end{array}$ & $\begin{array}{c}\text { Colony Count, } \\
\mathbf{3 7} \mathbf{~}^{\circ} \mathbf{C}\end{array}$ & Coliforms & Enterococcus & Clostridium & $\begin{array}{c}\text { Pseudomonas } \\
\text { Aeruginosa }\end{array}$ \\
\hline Mean difference & 49.00 & 41.95 & 2.63 & 1.76 & 9.67 & 30.25 \\
Standard error & 23.47 & 18.00 & 1.67 & 1.75 & 3.41 & 10.87 \\
$t$-test $p$-value & 0.049 & 0.030 & 0.132 & 0.327 & 0.010 & 0.050 \\
\hline
\end{tabular}

\subsection{Reverse Osmosis Results}

The RO unit has been operated with slow filtered water produced purely from surface water from 1 February 2017 to 10 July 2017. The river water was spiked with groundwater extracted from a nearby well during a second test period from 12 July 2017 to 2 November 2017. The groundwater contained dissolved iron in concentrations of $5-10 \mathrm{mg} / \mathrm{L}$ and manganese in concentrations of $2-5 \mathrm{mg} / \mathrm{L}$. Before spiking, dissolved iron concentrations were below $100 \mu \mathrm{g} / \mathrm{L}$ and manganese was below the detection limit $(10 \mu \mathrm{g} / \mathrm{L})$ above the filter. Dissolved iron concentration increased to 150-200 $\mu \mathrm{g} / \mathrm{L}$ and manganese to $300 \mu \mathrm{g} / \mathrm{L}$ above the filter after spiking.

In order to push the slow filtration system more toward anoxic conditions, fresh riverbed material from the Danube was placed on top of the sand in a $10 \mathrm{~cm}$ thick layer. Even after this, $1-4 \mathrm{mg} / \mathrm{L}$ dissolved oxygen could be observed in the filtrate, but dissolved iron concentration in the filtrate increased to 200-250 $\mu \mathrm{g} / \mathrm{L}$. As shown in Figure 7, the long-term permeability rate increased from $0.011 \mathrm{LMH} /$ bar/day to $0.017 \mathrm{LMH} /$ bar/day. LMH reprsenets the membrane flux and it stands for "liter per square meter per hour", $\mathrm{L} \cdot \mathrm{m}^{-2} \cdot \mathrm{h}^{-1}$. Divided by the transmembrane pressure and the elapsed time, it gives the average rate of permeability decrease.

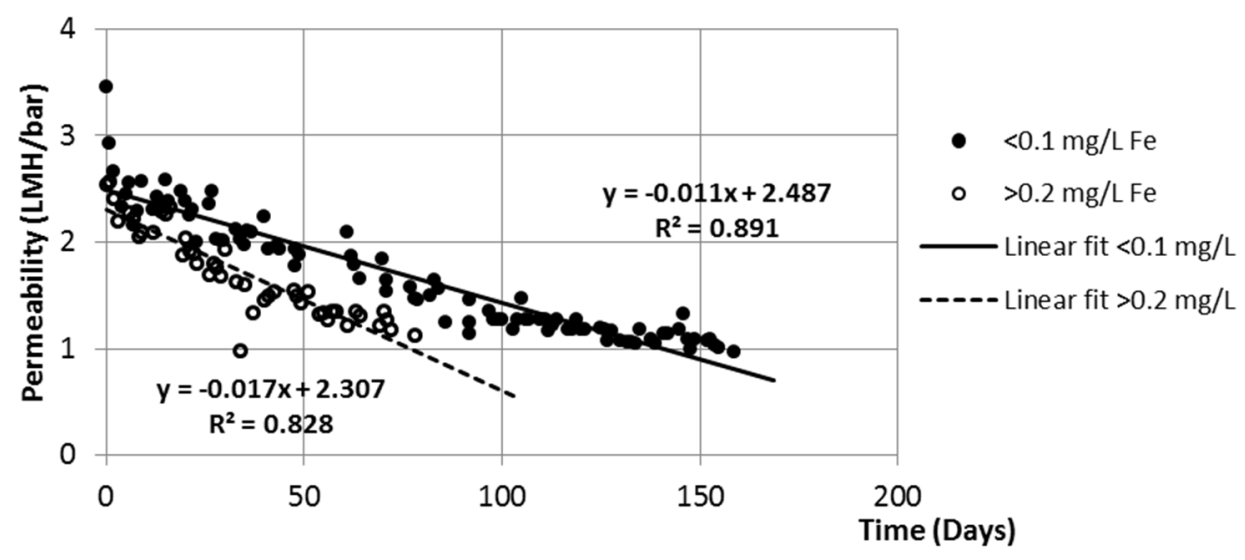

Figure 7. Relationship between permeability with $100 \mu \mathrm{g} / \mathrm{L}$ and $200 \mu \mathrm{g} / \mathrm{L}$ dissolved iron and time $\left(\mathrm{LMH}=\mathrm{L} \cdot \mathrm{m}^{-2} \cdot \mathrm{h}^{-1}\right)$.

Apart from the random errors due to the manual reading of pressure gauges and flow meters, the permeability shows a clear decreasing tendency, as expected. A sudden drop can be observed when the filtration is started after each chemical cleaning. After the first 1-2 days, the plotted linear tendency is present for a long duration (50-150 days). Even though the permeability decreased to one-third of its original value, it was possible to restore it.

\section{Discussion}

It has to be noted that indicator parameters are not well suited for the quantitative assessment of pathogens or microbial activity. These standard methods are primarily designed as safety indicators for distinguishing between the negative and positive (non-zero) samples. In order to assess microbiological activity and the biomass, other emerging methods are available such as ATP or RNA analysis, measurement of certain enzymes, etc. [18]. 
Due to the low number of bacteria in the river water, only less than 1 log removal values could be observed during the time of the experiment. The good quality of the river water can be explained by no wastewater discharge nor any polluting activity in the vicinity and the location of the water intake structure at a stagnant zone in the river. Most suspended solids from the main stream settle before they reach the inlet of the water intake.

Because of these low initial values, a strong reduction could only be observed for three parameters: colony count at different temperatures and Pseudomonas. Although colony count has the largest range in reduction (10-100\%), it gives the best proof of reduction in the number of microorganisms since it had the most positive samples in the river water. An even better reduction was achieved regarding Pseudomonas, however, two out of four samples from the river were found to be free of Pseudomonas.

The results obtained in this experiment for the reduction of microbiological indicator parameters are well within the range of previously reported values [7]. For Pseudomonas and total bacteria, $60 \%$ removal was obtained in small scale filter columns with $1 \mathrm{~m}$ thick sand layer and $0.15 \mathrm{~m} / \mathrm{h}$ loading rate. It was also found that Pseudomonas species dominate the bacterial biofilm [19]. During the interpretation of the results, it has to be taken into account that even though there is an overall reduction in microbiological activity due to substrate consumption, the developed biofilm itself can detach from the solid surfaces of the filter and may cause higher results in the samples. Small slow sand filters with a thin $15 \mathrm{~cm}$ fine sand layer were reported to reject coliforms with 90-97\% efficiency [20].

Due to the very low pathogen content of surface water involved in this demonstration, it is problematic to compare results with similar studies. A similar investigation on the application of reverse osmosis directly after bank filtration described in "Desalination and Water Purification Research and Development Program Report No. 122" [15], where coliforms ranged between 200-10,000 colony forming units (CFU) $/ 100 \mathrm{~mL}$ in three investigated river sites. The report also mentions $0.052-1.62 \mathrm{mg} / \mathrm{L}$ of iron and $0.05-0.617 \mathrm{mg} / \mathrm{L}$ of manganese in the bank filtered water used for reverse osmosis membrane feed from the Ohio, Missouri and Raccoon rivers. Total rejection of coliforms on the reverse osmosis was also reported [15].

The feed water quality requirement for the membranes involved in the current demonstration are less than $0.1 \mathrm{mg} / \mathrm{L}$ of total iron and manganese and less than $100 \mathrm{CFU} / \mathrm{mL}$ according to the manufacturer's suggestions.

The transport of slowly biodegradable organic matter in the surface water should be taken into account when the short distance to the extraction point is considered. Such materials are humic acids, lignin and another plant residues, which can be found in surface waters used for bank filtration. The biologically active layer and the subsequent adsorption processes during slow filtration are capable of reducing the concentration of such components [21]. If iron and manganese precipitates in the active layer due to the oxic conditions, it can be beneficial not only to the adsorption of the colloid material, but for the immobilization of microorganisms as well [22], as long as severe clogging can be avoided.

Since the experiment was conducted under circumstances characteristic for pure slow sand filtration, its results support the hypothesis that the thin boundary layer and a short $(1.2 \mathrm{~m})$ flow through a porous media can be responsible for as much as $80 \%$ or more reduction in the common microbiological indicator parameters. Compared with common flow path lengths at Hungarian bank filtration sites of 10-50 m and the high iron and manganese concentration in land-side groundwater, it is important to define the ideal flow path length during the design. This requires a cost-benefit analysis, especially when iron and manganese sensitive membrane technologies are to be installed.

\section{Conclusions}

In general, it is customary to increase the distance of the extraction element from the surface water boundary for safety considerations. In case of combined systems, when new post-treatment technologies such as ultrafiltration, nanofiltration or reverse osmosis with high pathogen removal efficiency are applied, shorter flow path lengths could be an advantage to prevent increased concentration of dissolved iron and manganese. In the case of RBF, there are severe uncertainties and 
safety considerations for the distance of the extraction point from the river. The most important is riverbed erosion, which heavily puts the extent of the biologically active zone into question. On the other hand, artificial structures such as filter dams with geotextile support may be adequate to provide proper conditions for short travel distances.

It was found that as long as the bank filtered water fulfills the required quality standards set by the manufacturer, the permeability of the reverse osmosis membrane can be sustained for a long time, even for 50-100 days. The quality of the pumped water as a mixture of bank filtrate and land-side groundwater is site specific and in Hungary, especially at the lower Danube region, tends to contain more than $0.2 \mathrm{mg} / \mathrm{L}$ of dissolved iron due to the groundwater flow. In order to make the long-term operation of reverse osmosis possible, short distances between the river bank and the extraction point will help to maintain oxic conditions and minimize the iron input from groundwater flow. Reverse osmosis is known to be capable of rejecting pathogens almost completely. Even if a higher number of bacteria break through the bank filtration because of the shorter distances, the risks should not be higher than for classic water treatment processes.

In this way, the natural system (the biologically active zone) can be utilized not only to decrease turbidity and reject a significant number of pathogens, but to reduce the biofouling potential of the membrane by the removal of easily degradable substrates which otherwise contribute to biofilm growth. Membrane filtration techniques have a high efficiency in pathogen rejection, but are sensitive to fouling caused by iron or manganese precipitation. When membrane filtration is applied, the decrease in the portion of land-side groundwater is of first priority and the pathogen rejection can be safely carried out with the combination of short filtration by RBF or other MAR schemes and membrane treatment.

Author Contributions: All authors collaborated in this work. Writing-Original Draft Preparation, E.S.; Writing-Review and Editing, Z.G.

Funding: All primary data was collected within the AquaNES project. This project has received funding from the European Union's Horizon 2020 Research and Innovation Program under grant no. 689450. www.aquanes-h2020. eu.

Acknowledgments: The authors would like to express their gratitude to the staff operating the pilot water treatment plant: Ilona Dalkó, Kitti Tafner and Tamás Papp in particular. The authors also acknowledge the helpful comments from T. Grischek during final paper preparation.

Conflicts of Interest: The authors declare no conflict of interest.

\section{References}

1. Dillon, P.; Stuyfzand, P.; Grischek, T.; Lluria, M.; Pyne, R.D.G.; Jain, R.C.; Bear, J.; Schwarz, J.; Wang, W.; Fernandez, E.; et al. Sixty years of global progress in managed aquifer recharge. Hydrogeol. J. 2018, 1-30. [CrossRef]

2. Salamon, E. Investigation of slow filtration followed by reverse osmosis (Lassú szúrés-fordított ozmózisos ivóvíz tisztítási technológiai sor vizsgálata). In Proceedings of the Membrane Technology Water Industry Day Conference, Budapest, Hungary, 9 November 2017.

3. Collins, M.R.; Eighmy, T.T.; Fenstermacher, J.M.; Spanos, S.K. Removing Natural Organic Matter by Conventional Slow Sand Filtration. J. Am. Water Works Assoc. 1992, 84, 80-90. [CrossRef]

4. Jenkins, M.W.; Tiwari, S.K.; Darby, J. Bacterial, viral and turbidity removal by intermittent slow sand filtration for household use in developing countries: Experimental investigation and modeling. Water Res. 2011, 45, 6227-6239. [CrossRef] [PubMed]

5. Hoffmann, A.; Gunkel, G. Bank filtration in the sandy littoral zone of Lake Tegel (Berlin): Structure and dynamics of the biological active filter zone and clogging processes. Limnologica 2011, 41, 10-19. [CrossRef]

6. Ray, C.; Grischek, T.; Schubert, J.; Wang, J.Z.; Speth, T.F. A Perspective of Riverbank Filtration. J. Am. Water Works Assoc. 2002, 94, 149-160. [CrossRef]

7. Seeger, E.M.; Braeckevelt, M.; Reiche, N.; Müller, J.A.; Kästner, M. Removal of pathogen indicators from secondary effluent using slow sand filtration: Optimization approaches. Ecol. Eng. 2016, 95, 635-644. [CrossRef] 
8. Pfannes, K.R.; Langenbach, K.M.W.; Pilloni, G.; Stührmann, T.; Euringer, K.; Lueders, T.; Neu, T.R.; Müller, J.A.; Kästner, M.; Meckenstock, R.U. Selective elimination of bacterial faecal indicators in the Schmutzdecke of slow sand filtration columns. Appl. Microbiol. Biotechnol. 2015, 99, 10323-10332. [CrossRef] [PubMed]

9. Weiss, W.J.; Bouwer, E.J.; Aboytes, R.; LeChevallier, M.W.; O'Melia, C.R.; Le, B.T.; Schwab, K.J. Riverbank filtration for control of microorganisms: Results from field monitoring. Water Res. 2005, 39, 1990-2001. [CrossRef] [PubMed]

10. Van Driezum, I.H.; Chik, A.H.S.; Jakwerth, S.; Lindner, G.; Farnleitner, A.H.; Sommer, R.; Blaschke, A.P.; Kirschner, A.K.T. Spatiotemporal analysis of bacterial biomass and activity to understand surface and groundwater interactions in a highly dynamic riverbank filtration system. Sci. Total Environ. 2018, 627, 450-461. [CrossRef] [PubMed]

11. Grischek, T.; Bartak, R. Riverbed Clogging and Sustainability of Riverbank Filtration. Water 2016, 8, 604. [CrossRef]

12. des Tombe, B.F.; Bakker, M.; Schaars, F.; van der Made, K.-J. Estimating Travel Time in Bank Filtration Systems from a Numerical Model Based on DTS Measurements. Ground Water 2018, 56, 288-299. [CrossRef] [PubMed]

13. Albergamo, V.; Blankert, B.; Cornelissen, E.R.; Hofs, B.; Knibbe, W.-J.; van der Meer, W.; de Voogt, P. Removal of polar organic micropollutants by pilot-scale reverse osmosis drinking water treatment. Water Res. 2019, 148, 535-545. [CrossRef] [PubMed]

14. Davies, P.A. A solar-powered reverse osmosis system for high recovery of freshwater from saline groundwater. Desalination 2011, 271, 72-79. [CrossRef]

15. Gooters, S. The Role of Riverbank Filtration in Reducing the Costs of Impaired Water Desalination; Desalination and Water Purification Research and Development Program Report No. 122; Department of the Interior, Bureau of Reclamation, Water Treatment Engineering and Research Group: Denver, CO, USA, 2006.

16. Argo, D.R. Use of Lime Clarification and Reverse Osmosis in Water Reclamation. J. Water Pollut. Control Fed. 1984, 56, 1238-1246.

17. MSZ EN ISO 19458:2007 Water Quality—Sampling for Microbiological Analysis (ISO 19458:2006) 21; International Organization for Standardization: Geneva, Switzerland, 2006.

18. Chan, S.; Pullerits, K.; Riechelmann, J.; Persson, K.M.; Rådström, P.; Paul, C.J. Monitoring biofilm function in new and matured full-scale slow sand filters using flow cytometric histogram image comparison (CHIC). Water Res. 2018, 138, 27-36. [CrossRef] [PubMed]

19. Calvo-Bado, L.A.; Pettitt, T.R.; Parsons, N.; Petch, G.M.; Morgan, J.A.W.; Whipps, J.M. Spatial and Temporal Analysis of the Microbial Community in Slow Sand Filters Used for Treating Horticultural Irrigation Water. Appl. Environ. Microbiol. 2003, 69, 2116-2125. [CrossRef] [PubMed]

20. Guchi, E.; Leta, S.; Boelee, E. Efficiency of slow sand filtration in removing bacteria and turbidity from drinking water in rural communities of central Ethiopia. Afr. J. Microbiol. Res. 2014, 8. submitted.

21. Mo, J.; Yang, Q.; Zhang, N.; Zhang, W.; Zheng, Y.; Zhang, Z. A review on agro-industrial waste (AIW) derived adsorbents for water and wastewater treatment. J. Environ. Manag. 2018, 227, 395-405. [CrossRef] [PubMed]

22. Bouabidi, Z.; El-Naas, M.; Zhang, Z. Immobilization of microbial cells for the biotreatment of wastewater: A review. Environ. Chem. Lett. 2018, 1-17. [CrossRef]

(C) 2019 by the authors. Licensee MDPI, Basel, Switzerland. This article is an open access article distributed under the terms and conditions of the Creative Commons Attribution (CC BY) license (http:/ / creativecommons.org/licenses/by/4.0/). 